Environmental Variability of Thousand Kernel Weight in Maize Hybrids of Different Maturity Groups

Okolinska varijabilnost mase tisuću zrna kod hibrida kukuruza različitih skupina zriobe

Stepinac, D., Šarčević, H., Buhiniček, I., Jukić, M., Marković, B., Jambrović, A., Pejić, I., Šimić, D.

Poljoprivreda/Agriculture

ISSN: $1848-8080$ (Online)

ISSN: 1330-7142 (Print)

https://doi.org/10.18047/poljo.27.2.6

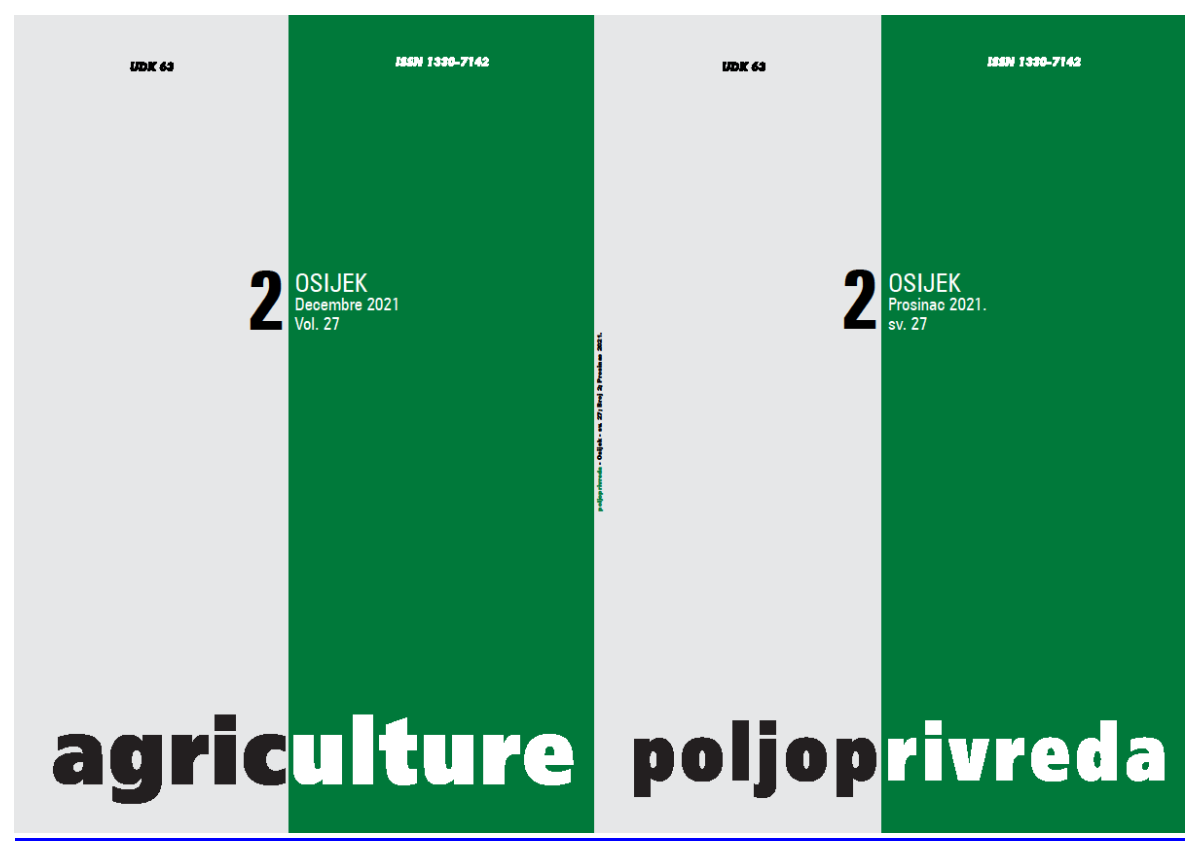

Fakultet agrobiotehničkih znanosti Osijek, Poljoprivredni institut Osijek

Faculty of Agrobiotechnical Sciences Osijek, Agricultural Institute Osijek 
ISSN $1330-7142$

$U D K=633.15: 631.559$

https://doi.org/10.18047/poljo.27.2.6

\title{
ENVIRONMENTAL VARIABILITY OF THOUSAND KERNEL WEIGHT IN MAIZE HYBRIDS OF DIFFERENT MATURITY GROUPS
}

Stepinac, D. ${ }^{(1)}$, Šarčević, H. ${ }^{(2,4)}$, Buhiniček, I. ${ }^{(1)}$, Jukić, M. ${ }^{(1)}$, Marković, B. ${ }^{(3)}$, Jambrović, A. ${ }^{(4,5)}$, Pejić, I. ${ }^{(2,4)}$, Šimić, $D .{ }^{(4,5)}$

Original scientific paper

Izvorni znanstveni članak

\begin{abstract}
SUMMARY
Thousand kernel weight (TKW) is an important yield component trait affected by the environmental conditions. This study's objectives were to determine an environmental variability for the TKW in 32 maize hybrids, sorted in four FAO maturity groups (FA0300, 400, 500 and 600), and to compare 12 environments in Croatia (six locations in two years) according to the joint linear regression and stability analyses across the maturity groups. In general, the effects of the environment, genotype, and their interaction (GEI) were significant. A three-factor ANOVA revealed the greatest and highly significant year effect, while the location effect was nonsignificant across all four $F A O$ groups. A stability analysis did not detect any preferences with regard to the locations and trends across the FAO groups. It indicates that all locations in the Pannonian region included in this study were suitable for an evaluation of the TKW in maize genotypes belonging to all maturity groups. The TKW seems to be an appropriate yield-component trait for maize breeding due to a high heritability and linear GEI nature.
\end{abstract}

Keywords: genotype $\times$ environment interaction (GEI), maize, stability analysis, locations, thousand kernel weight

\section{INTRODUCTION}

A grain yield, as the most important agronomic trait in maize, is associated with several yield component traits (Stuber et al., 1987). A kernel weight is one of them, measured as a "thousand kernel weight" (TKW), being strongly affected by the growth conditions (Zhou at al., 2016), especially by the drought and heat stresses during the grain-filling period (Ou-Lee et al., 1985; Westgate et al., 1994). To assure a stable maize yield, it is important to determine the environmental effects and their interactions with the TKW genotypes. While a genotype and environment interaction and a stability analyses concerning a grain yield in maize are well documented, also implying the studies conducted in the Greater Pannonian Region (e.g., the recent studies by Stojaković et al., 2015; Zorić et al., 2017; and Branković-Radojčić et al., 2018), the reports about an environmental variation and its interaction with a genotypic variation of the TKW is still lacking. Mitrović

(1) Domagoj Stepinac, Mag. Eng. Agr., Ivica Buhiniček, Ph. D., Mirko Jukić, Ph. D. - Bc Institute for Breeding and Production of Field Crops, Dugoselska 7, 10370 Rugvica, Dugo Selo, Croatia, (2) Prof. Dr. Hrvoje Šarčević, Prof. Dr. Ivan Pejić - University of Zagreb, Faculty of Agriculture, Svetošimunska cesta 25, 10000 Zagreb, Croatia, (3) Bojan Marković, Mag. Eng. Agr. - CBM AGRO, Antuna Kanižlića 47, 31000 Osijek, Croatia, (4) Antun Jambrović, Ph.D., Prof. Dr. Ivan Pejić, Assoc. Prof. Domagoj Šimić (domagoj.simic@poljinos.hr) - Centre of Excellence for Biodiversity and Molecular Plant Breeding, Svetošimunska cesta 25, 10000 Zagreb, Croatia, (5) Agricultural Institute Osijek, Južno predgrađe 17, 31000 Osijek, Croatia 
et al. (2016) have analyzed the environmental variation of a hundred kernel weight, together with its interaction with the long breeding periods in Serbia, but only a late maturity group was included in the study. However, the relationships between the yield, TKW, and maturity are not straightforward (Milander et al., 2017). When the environmental effects are to be involved, the relationship could be more challenging, exacerbated by a global climate change.

This study's objectives were to determine an environmental variability for the TKW in maize hybrids belonging to four FAO maturity groups (FAO 300, 400, 500 and 600 ) and to compare 12 environments and six locations according to the joint linear regression and stability analyses across the maturity groups.

\section{MATERIAL AND METHODS}

A total of 32 maize hybrids belonging to the FAO $300,400,500$ and 600 maturity groups (eight hybrids in each maturity group) were evaluated during the growing seasons in 2017 and 2018. The two years field experiment was described in detail by Pandžić et al. (2021), including a comprehensive meteorological and agronomic information. In this study, the data from six locations, i.e., Šašinovec, Rugvica, Osijek, Beli Manastir, Tovarnik and Kutjevo, were selected, corresponding to the locations L2, L5, L8, L9 and L10 presented by Pandžić et al. (2021). Each FAO group was analyzed separately, whereby a randomized complete block design with four replicates was used for all trials. The size of the four-row experimental plots amounted to $11.2 \mathrm{~m}^{2}$, an inter-row distance was $0.7 \mathrm{~m}$, and a planting density was adjusted according to the maturity groups. Fertilization, weed control, and cultural practices were performed according to the practical farming. The grain yield data $\left(\mathrm{t} \mathrm{ha}^{-1}\right)$ were recorded in each environment and calculated to a $14 \%$ of moisture. Based on a sample of 10 random ears per plot, thousand kernel weight (TKW) was determined, adjusted to a $14 \%$ moisture and expressed in grams. Each year-location combination was considered as an "environment" (see, e.g., Eberhart and Russel, 1966), analyzed as a series of random locations with an entry means and an effective error variance (Cochran and Cox, 1957), which were used for a combined analysis. In a combined ANOVA, a sum of squares of a genotype-environment interaction was partitioned according to a "symmetrical joint linear regression analysis" (DeLacy et al, 1996) proposed by Wright, 1971, and Utz, 1972, according to the following model:

$$
y_{i j}=m+g_{i}+e_{j}+a g_{i} e_{j}+c_{j} g_{i}+b_{i} e_{j}+r_{i j}
$$

where $m$ is a grand mean over all genotypes and environments, $g_{i}$ is a genotype effect, $e_{j}$ is an environment effect and $a g_{i} e_{j}$ is a joint regression effect with a concordance parameter $a$. The joint regression effect was replaced by Tukey's non-additivity test (Tukey, 1949), as suggested by Utz (1972): $b_{i}$ is a regression coefficient for the genotype $i, c_{j}$ is a regression coefficient for the environment $j$ and $r_{i j}$ is residual. Regression coefficients $\left(b_{i}\right)$ and deviation mean squares $\left(s^{2}{ }_{d i}\right)$ were employed as the yield stability parameters for each environment (Eberhart and Russel, 1966). Bartlett's homogeneity test within the environment error variances provided a nonsignificant chi-square, so a homogeneity hypothesis was accepted in this case. Heritability was estimated on an entry-mean basis (Hallauer et al., 2010), as follows: $H^{2}=\frac{\sigma_{G}^{2}}{\sigma_{G}^{2}+\sigma_{G \times E}^{2}+\sigma_{e}^{2}}$, where $\sigma_{G}^{2}$ represents a genotypic variance, $\sigma_{G X E}^{2}$ represents a genotype $\times$ environment interaction variance, and $\sigma_{e}^{2}$ is a residual variance. The PLABSTAT program package (Utz, 1995) was used for a statistical analysis.

\section{RESULTS AND DISCUSSION}

The data pertaining to each environment were analyzed separately, manifesting the highly significant effects of genotypes on all environments (data not depicted). The environmental means differed considerably across the $\mathrm{FAO}$ groups concerning a grain yield and the TKW (Figure 1). Generally, concerning the grain yield, the environmental mean values were lower in 2017. On the other hand, there was a greater variation of the TKW in 2017 than in 2018, resulting in the TKW mean values ranging between 270 to approximately $400 \mathrm{~g}$. The highest TKW means were noted in two environments in 2017, pertaining to the FAO 600 hybrids. Mitrović et al. (2016) have presented the similar kernel weight results for the FAO 600 hybrids, released in Serbia between 1978 and 2011. A correlation coefficient between a grain yield and the TKW was $r=0.56$. A companion paper by Pandžić et al. (2021) has demonstrated that a grain yield reduction was primarily affected by the TKW, emphasizing an importance of sufficient grain filling. 


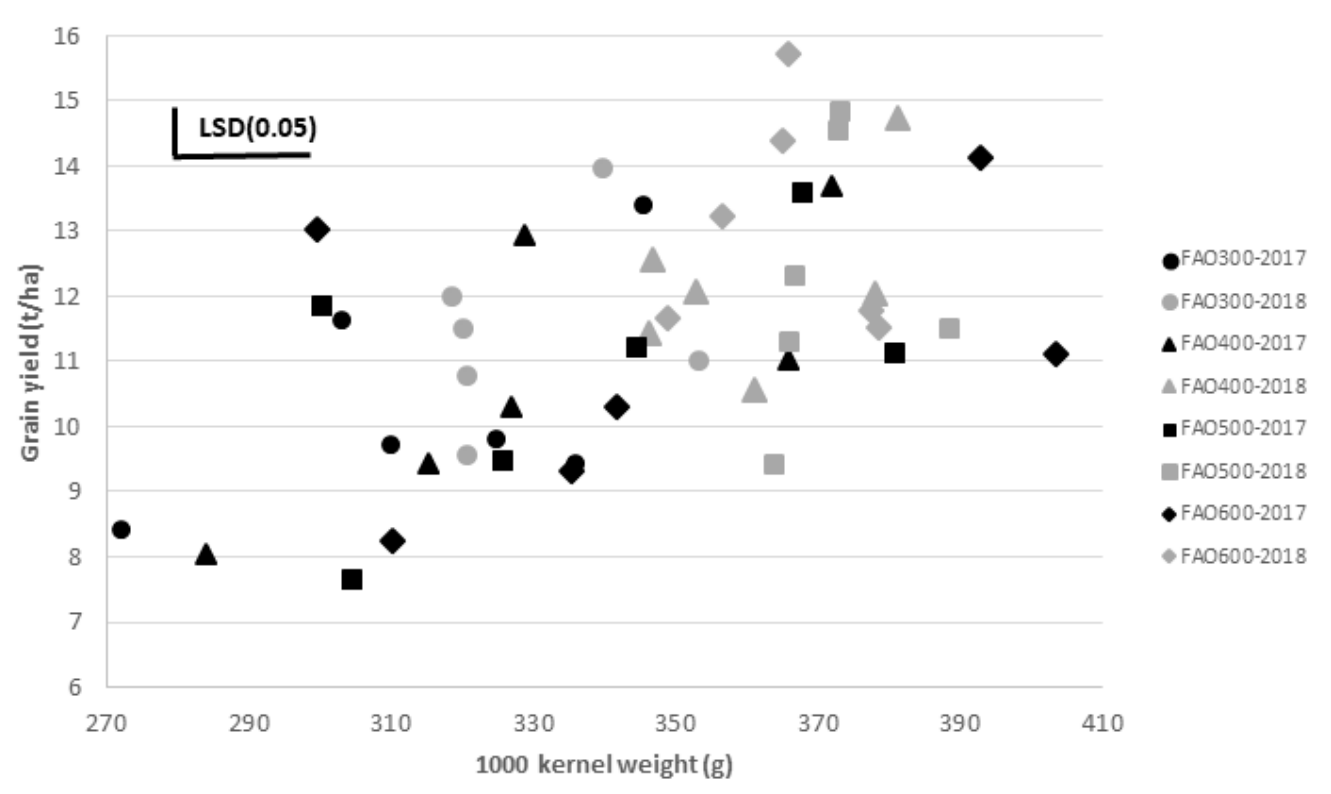

Figure 1. A relationship between a thousand kernel weight (TKW) and a grain yield based on the environmental means in six locations and two years (12 environments), averaged over the eight maize genotypes in each of the four FAO groups. LSD (0.05) denotes least significant difference at the $\mathbf{0 . 0 5}$ probability level

Grafikon 1. Odnos između mase tisuće zrna i prinosa zrna na osnovi okolinskih srednjih vrijednosti na šest lokacija u dvjema godinama (12 okolina), uprosječenih za osam genotipova u svakoj od četiriju FAO skupina. LSD (0.05) označuje najmanju značajnu razliku na razini vjerojatnosti od 0.05

A three-factor analysis of variance (ANOVA) revealed the greatest and highly significant year effect across all four FAO groups (Table 1). A location effect was consistently insignificant, whereas a genotype effect was significant for the FAO groups 300,400 , and 500. A location $\times$ year interaction $(L \times Y)$ was highly significant across all FAO groups. The significance of other interactions was inconsistent across the FAO groups.

Table 1. A three-factor ANOVA for a thousand kernel weight (TKW) in eight maize genotypes of each of the four FAO maturity groups, i.e., 300, 400, 500 and 600, respectively (a total of 32 hybrids), grown at six locations in two years

Tablica 1. Kombinirana tročimbenična ANOVA za masu tisuću zrna kod osam genotipova kukuruza u svakoj skupini zriobe FAO 300, 400, 500 i 600 (ukupno 32 hibrida), posijanih na šest lokacija u dvjema godinama

\begin{tabular}{|c|c|c|c|c|c|}
\hline \multirow{2}{*}{$\begin{array}{l}\text { Source of Variation / } \\
\text { Izvor variranja }\end{array}$} & \multirow{2}{*}{$\begin{array}{c}\text { Degrees } \\
\text { of freedom / } \\
\text { Stupnjevi slobode }\end{array}$} & \multicolumn{4}{|c|}{ Mean square / Varijanca } \\
\hline & & FA0 300 & FAO 400 & FA0 500 & FAO 600 \\
\hline Year $(Y)$ / Godina $(Y)$ & 1 & $4472.7^{* *}$ & $20029.7^{* *}$ & $29041.0^{* *}$ & $7943.2^{* *}$ \\
\hline Location (L) / Lokacija (L) & 5 & $923.5 \mathrm{~ns}$ & 382.0ns & $3280.4 \mathrm{~ns}$ & $8737.4 \mathrm{~ns}$ \\
\hline Genotype (G) / Genotip (G) & 7 & $2914.8 * *$ & $6704.1 * *$ & $3387.2^{* *}$ & $2413.5 n s$ \\
\hline$L \times Y$ & 5 & $6293.9 * *$ & $6648.8^{* *}$ & $6079.6^{* *}$ & $6863.9 * *$ \\
\hline $\mathrm{G} \times \mathrm{Y}$ & 7 & $249.7 \mathrm{~ns}$ & $435.6^{*}$ & $348.1 \mathrm{~ns}$ & $1889.1^{* *}$ \\
\hline $\mathrm{G} \times \mathrm{L}$ & 35 & $284.4^{*}$ & $178.4 \mathrm{~ns}$ & $200.5 \mathrm{~ns}$ & $245.5 n s$ \\
\hline$G \times L \times Y$ & 35 & $129.6^{*}$ & $140.3 \mathrm{~ns}$ & $238.2^{* *}$ & $184.9 *$ \\
\hline
\end{tabular}

**, * Significant at the 0.01 and 0.05 probability levels, respectively / statistički značajno na razini vjerojatnosti od 0,01 odnosno 0,05; ns nonsignificant / nije statistički značajno

In a combined two-factor ANOVA, the genotypes, environments, and their interaction were highly significant for the TKW across the FAO groups (Table 2). Heritability estimates were reasonably high, indicating the relatively low variances of a $\mathrm{G} \times \mathrm{E}$ interaction and residuals. The partitioning of a $\mathrm{G} \times \mathrm{E}$ sum of squares according to a symmetrical joint linear regression analy- sis has revealed non-significantTukey's test, heterogeneity of environmental regressions and heterogeneity of genotypic regressions. Non-significant Tukey's test indicates that a TKW-related $\mathrm{G} \times \mathrm{E}$ interaction has a more linear nature, rather than a complex one. It justifies a further examination of stability parameters for each environment separately. 
Table 2. ANOVA for a thousand kernel weight (TKW) (g) of eight maize genotypes of each of the four maturity groups, FAO 300, 400, 500 and 600 (total of 32 hybrids), respectively, across 12 environments and heritability estimates, with corresponding standard error (SE)

Tablica 2. Kombinirana ANOVA za masu tisuću zrna (g) osam genotipova kukuruza u svakoj skupini zriobe FAO 300 , 400, 500 i 600 (ukupno 32 hibrida) uzgojenih u dvanaest okolina i vrijednosti heritabilnosti s pripadajućom standardnom pogreškom (SE)

\begin{tabular}{|c|c|c|c|c|c|}
\hline \multirow{2}{*}{$\begin{array}{l}\text { Source of Variation / } \\
\text { Izvor variranja }\end{array}$} & \multirow{2}{*}{$\begin{array}{c}\text { Degrees } \\
\text { of freedom / } \\
\text { Stupnjevi slobode }\end{array}$} & \multicolumn{4}{|c|}{ Mean square / Varijanca } \\
\hline & & FAO 300 & FAO 400 & FAO 500 & FAO 600 \\
\hline Environments (E) / Okoline (E) & 11 & $3687.2^{* *}$ & $6579.4^{* *}$ & $6894.7^{* *}$ & $7813.6^{* *}$ \\
\hline Genotypes (G) / Genotipovi (G) & 7 & $2914.8^{* *}$ & $6704.1^{* *}$ & $3387.2^{* *}$ & $2413.5^{* *}$ \\
\hline Interaction $\mathrm{G} \times \mathrm{E}$ - Interakcija $\mathrm{G} \times \mathrm{E}$ & 77 & $210.9 * *$ & $184.5^{* *}$ & $231.1^{* *}$ & $367.4 * *$ \\
\hline Tukey's test / Tukeyev test & 1 & $104.9 \mathrm{~ns}$ & $183.3 \mathrm{~ns}$ & $22.5 \mathrm{~ns}$ & 333.6 ns \\
\hline $\begin{array}{l}\text { Heterogeneity of environmental regressions / } \\
\text { Heterogenost okolinske regresije }\end{array}$ & 6 & $40.9 \mathrm{~ns}$ & $270.2 \mathrm{~ns}$ & $312.8 \mathrm{~ns}$ & $366.0 \mathrm{~ns}$ \\
\hline $\begin{array}{l}\text { Heterogeneity of genotypic regressions / } \\
\text { Heterogenost genotipske regresije }\end{array}$ & 10 & $242.5 \mathrm{~ns}$ & $146.0 \mathrm{~ns}$ & $58.3 \mathrm{~ns}$ & $146.1 \mathrm{~ns}$ \\
\hline Residual deviations / Residualne devijacije & 60 & 224.4 & 182.3 & 255.2 & 405.0 \\
\hline Pooled error / Skupna pogreška & 252 & 78.27 & 118.5 & 132.0 & 122.2 \\
\hline Heritability (SE) / Heritabilnost (SE) & & $92.8(3.6)$ & $97.3(1.4)$ & $93.2(3.4)$ & $84.8(5.6)$ \\
\hline
\end{tabular}

** Significant at the 0.01 probability level / statistički značajno na razini vjerojatnosti od 0,01; ns nonsignificant / nije statistički značajno

Twelve environments differed in their stability parameters, but there was no consistent trend for both a regression coefficient and a deviation mean square across the environments and maturity groups (Table 3). Generally, the highest regression coefficient values were detected for the FAO 300 maturity group, while there were no $b_{i}$ values greater than 1.00 for the FA0 600 maturity group. On average, the greatest $s^{2}{ }_{d i}$ values were observed in the FAO 600 hybrids, with no obvious trend across the environments. Generally, our results suggest that a TKW-related stability analysis did not detect any preferences among the locations and no trends across the FAO groups. Comparable findings pertaining to a grain yield stability analysis in a similar location set were presented by Šimić et al. (2003).

Table 3. Regression coefficient $\left(b_{i}\right)$ and a deviation mean square $\left(\mathbf{s}^{2}{ }_{\mathrm{di}}\right)$, stability parameters for a thousand kernel weight in 12 environments in Croatia in eight maize hybrids in each of the four FAO maturity groups.

Tablica 3. Regresijski koeficijent $\left(b_{j}\right)$ i varijanca odstupanja $\left(s^{2}{ }_{d i}\right)$, parametri stabilnosti za masu tisuću zrna u 12 okolina u Hrvatskoj kroz osam hibrida kukuruza u svakoj od četiriju FAO-ovih skupina zriobe.

\begin{tabular}{|c|c|c|c|c|c|c|c|c|}
\hline \multirow[t]{2}{*}{$\begin{array}{l}\text { Environment / } \\
\text { Okolina }\end{array}$} & \multicolumn{4}{|c|}{$\begin{array}{l}\text { Regression coefficient }\left(b_{i}\right) / \\
\text { Regresijski koeficijent }\left(b_{i}\right)\end{array}$} & \multicolumn{4}{|c|}{$\begin{array}{c}\text { Deviation mean square }\left(\mathrm{s}^{2}{ }_{\mathrm{d}}\right) / \\
\text { Varijanca odstupanja }\left(\mathrm{s}_{d i}^{2}\right)\end{array}$} \\
\hline & FAO 300 & FAO 400 & FAO 500 & FA0 600 & FAO 300 & FAO 400 & FAO 500 & FA0 600 \\
\hline Šašinovec17 & 1.23 & 0.90 & 0.40 & 0.75 & 179 & 143 & 285 & 464 \\
\hline Rugvica17 & 1.50 & 0.48 & 0.92 & 0.29 & 343 & 90 & 328 & 601 \\
\hline Osijek17 & 1.19 & 0.58 & 0.92 & 0.53 & 172 & 170 & 216 & 169 \\
\hline B. Manastir17 & 0.89 & 0.48 & 0.63 & 0.40 & 120 & 512 & 350 & 491 \\
\hline Tovarnik17 & 0.99 & 0.30 & 1.19 & 0.36 & 296 & 109 & 175 & 445 \\
\hline Kutjevo17 & 0.59 & 0.54 & 1.12 & 0.58 & 89 & 89 & 244 & 327 \\
\hline Šašinovec18 & 1.26 & 0.70 & 1.12 & 0.63 & 110 & 25 & 187 & 345 \\
\hline Rugvica18 & 1.28 & 0.65 & 0.80 & 0.62 & 197 & 281 & 393 & 487 \\
\hline Osijek18 & 1.40 & 0.50 & 0.71 & 0.30 & 116 & 105 & 284 & 240 \\
\hline B. Manastir18 & 0.76 & 0.45 & 1.09 & 0.76 & 226 & 172 & 98 & 212 \\
\hline Tovarnik18 & 0.52 & 0.35 & 0.88 & 0.43 & 367 & 264 & 148 & 131 \\
\hline Kutjevo18 & 0.39 & 0.54 & 0.37 & 0.33 & 67 & 128 & 150 & 497 \\
\hline
\end{tabular}


However, Pandžić et al. (2021) documented that a moderate 2017 drought has differently affected a grain yield reduction concerning the locations throughout Croatia's Pannonian portion. Compared to the year 2018, a yield reduction in 2017 amounted to $13 \%$ in the Western part and $20 \%$ in the Eastern part, respectively.

\section{CONCLUSIONS}

The results of a TKW analysis have manifested a considerable difference between the years without an overall tangible location effect. Moreover, a weak location effect was consistent in all four FAO maturity groups. These results indicate that all locations in the Pannonian region included into this study were suitable for a TKW evaluation in maize genotypes affiliated with all maturity groups. A relatively high heritability and a less complex (i.e., linear) nature of a genotype $x$ environment interaction render the TKW as a yield-component trait, attractive for the maize breeding programs.

\section{ACKNOWLEDGEMENT}

The research was performed within the AGRODROUGHT-ADAPT project (PKP-2016-06-8290), funded by the Environmental Protection and Energy Efficiency Fund (FZOEU) and the Croatian Science Foundation (HRZZ) within a Republic of Croatia's Government program for the encouragement of research and the development of activities in the area of climate change adaptation.

\section{REFERENCES}

1. Branković-Radojčić, D., Babić, V., Girek, Z., Živanović, T., Radojcić, A., Filipović, M., \& Srdić, J. (2018). Evaluation of maize grain yield and yield stability by AMMI analysis. Genetika 50(3) 1067-1080. https://doi.org/10.2298/GENSR1803067B

2. Cochran, W. G. (1957). Experimental designs 2nd ed. John wiley \& sons.

3. Eberhart, S.A. \& Russel, W.A. (1966). Stability parameters for comparing varieties 1. Crop science, 6(1), 36-40. https://doi.org/10.2135/cropsci1966.0011183X000600010011x

4. DeLacy, I. H., Basford, K. E., Cooper, M., Bull, J. K., \& McLaren, C. G. (1996). Analysis of multi-environment trials-an historical perspective. Plant adaptation and crop improvement, 39124.

5. Hallauer, A. R., Carena, M. J., \& Filho, J. B. M. (2010). Quantitative Genetics in Maize Breeding. Springer. https://doi.org/10.1007/978-1-4419-0766-0

6. Milander, J., Jukić, Ž., Mason, S., Galusha, T., \& Kmail, Z. (2017). Hybrid maturity influence on maize yield and yield component response to plant population in Croatia and Nebraska. Cereal Research Communications 45(2), 326-335. https://doi.org/10.1556/0806.45.2017.015
7. Mitrović, B., Stojaković, M., Zorić, M., Stanisavljević, D., Bekavac, G., Nastasić, A., \& Mladenov, V. (2016). Genetic gains in grain yield, morphological traits and yield stability of middle-late maize hybrids released in Serbia between 1978 and 2011. Euphytica 211(3), 321330. https://doi.org/10.1007/s10681-016-1739-6

8. Ou-Lee, T. M., \& Setter, T. L. (1985). Effect of increased temperature in apical regions of maize ears on starchsynthesis enzymes and accumulation of sugars and starch. Plant Physiol. 79(3), 852-855. https://doi.org/10.1104/pp.79.3.852

9. Pandžić, K., Likso, T., Pejić, I., Šarčević, H., Pecina, M., Šestak, I., Tomšić, D., Mahović, N. S. (2021). Application of the Self-Calibrated Palmer Drought Severity Index for Estimation of Drought Impact on Maize Grain Yield in Pannonian Part of Croatia. Preprint https://doi.org/10.21203/rs.3.rs-219077/v1

10. Stojaković, M., Mitrović, B., Zorić, M., Ivanović, M., Stanisavljević, D., Nastasić, A., \& Dodig, D. (2015). Grouping pattern of maize test locations and its impact on hybrid zoning. Euphytica 204(2), 419-431.

11. Stuber, C. W., Edwards, M. D. A., \& Wendel, J. F. (1987). Molecular Marker-Facilitated Investigations of Quantitative Trait Loci in Maize. II. Factors Influencing Yield and its Component Traits. Crop Sci 7(4), 639-648.

12. Šimić, D., Gunjača, J., Zdunić, Z., Brkić, I., \& Kovačević, J. (2003). Biometrical characterization of test sites for maize breeding. Poljoprivreda 9(2), 18-24.

13. Tukey, J.W. (1949). One degree of freedom for nonadditivity. Biometrics 5, 232-242.

14. Utz, H.F. (1972). Die Zerlegung der Genotyp $\times$ Umwelt Interaktionen. EDV in Medizin und Biologie, Band 3, Heft 2:52-59

15. Utz, H.F. (1995). PLABSTAT Version M. Ein Computerprogramm zur statistischen Analyse von pflanzenzüchterischen Experimenten. Selbstverlag Universität Hohenheim, Stuttgart.

16. Westgate, M. E. (1994). Water status and development of the maize endosperm and embryo during drought. Crop Sci 34(1), 76-83.

17. Wright, A.J. (1971). The analysis and prediction of some two factor interactions in grass breeding. The Journal of Agricultural Science 76, 301-306.

18. Zhou, B., Yue, Y., Sun, X., Wang, X., Wang, Z., Ma, W., \& Zhao, M. (2016). Maize grain yield and dry matter production responses to variations in weather conditions. Agron. J. 108(1), 196-204. https://doi.org/10.2134/agronj2015.0196

19. Zorić, M., Gunjača, J., \& Šimić, D. (2017). Genotypic and environmental variability of yield from seven different crops in Croatian official variety trials and comparison with on-farm trends. The Journal of Agricultural Science 155(5), 804-811. https://doi.org/10.1017/S0021859616000903 


\section{OKOLINSKA VARIJABILNOST MASE TISUĆU ZRNA KOD HIBRIDA KUKURUZA RAZLIČITIH SKUPINA ZRIOBE}

\section{SAŽETAK}

Masa tisuću zrna (TKW) važno je svojstvo - komponenta prinosa koja je pod utjecajem okolinskih čimbenika. Ciljevi su ovoga rada odrediti okolinsku varijabilnost TKW-a 32 hibrida kukuruza kategorizirana u četiri FAO-ve skupine zriobe (FAO 300, 400, 500 i 600) i usporediti 12 okolina u Hrvatskoj (šest lokacija u dvjema godinama) prema združenoj linearno-regresijskoj analizi i analizi stabilnosti po grupama zriobe. Općenito, učinci okoline, genotipa i njihove interakcije (GEI) bili su statistički značajni. Tročimbenična ANOVA pokazala je najveći i visoko signifikantan učinak godine, dok učinak lokacije nije bio statistički značajan u sve četiri FAO-ve skupine. Analiza stabilnosti nije detektirala preferencije među okolinama niti trend pod FAO-vim skupinama. Naši rezultati ukazuju da su sve okoline u Panonskoj regiji uključene u istraživanje pogodne za procjenu TKW-a kod hibrida kukuruza svih FAO-vih skupina. TKW se pokazao prikladnom komponentom prinosa za oplemenjivanje kukuruza zbog visoke heritabilnosti i linearne naravi interakcije GEl-ja.

Ključne riječi: interakcija genotip × okolina, kukuruz, analiza stabilnosti, lokacije, masa tisuću zrna

(Received on March 16, 2021; accepted on October 15, 2021 - Primljeno 16. ožujka 2021.; prihvaćeno 15. listopada 2021.) 